\section{English Today}

\section{Notes for contributors}

(1) Academic research-based articles can be of two types. Those intended for scrutiny by the journal editors alone can range up to c.4,000 words in length. Those which authors wish to go forward to further scrutiny beyond the editorial team (that is, for peer review) can range up to c.6,000 words. Authors should make it clear whether they wish their submissions to be for 'editor review' or 'peer review'. Although every effort will be made to reach a decision on peer-review articles quickly, delays might sometimes occur in this process.

(2) Shorter items of comment and information, and reviews of print and electronic materials, are also welcome, and should be in the 500- to 2,000-word range.

(3) Material is managed by email and attachment to and from the editors, <englishtoday@ cambridge.org>

(4) Subsidiary text and illustrative material (lists, specimens, photographs, diagrams, and cartoons, etc.) can be added to articles, where necessary in numbered panels and tables, and are encouraged. Any notes should be concise, and references/ bibliography should be limited to the content of the paper. Website references should be in a list of their own after all other material.

(5) Every effort is made to retain distinctive usage and conventions, such as British or American spelling, special punctuation, and IPA symbols. Subheadings should be used in longer texts, and if not provided may be added. When contributors receive page proofs for checking, these should be dealt with quickly, preferably by email and attachment.

(6) Once a deadline for finalizing an article is agreed every effort should be made to keep to it, and the Editors should be informed as soon as possible if any change of circumstances occurs, so that any necessary adjustments may be made smoothly.

(7) Notification of the acceptance of an article for publication may be accompanied by copies of a Cambridge copyright release form, one to be retained, the other to be returned (completed and signed).

(8) The author(s) of a submission should provide 100-150 words of biography (per person).

(9) Prospective writers who are not regular readers of ET should study the journal before submitting material. Preferably they should write/email to introduce themselves, proposing a topic and providing a plan or specimen. Every effort is made to reply quickly, but this is not always possible.

(10) Unsolicited articles that could interest readers of ET but that were not written with the journal in mind are usually not suitable without a degree of rewriting and restructuring. Circumstances vary, and it may or may not be possible for the Editors to advise on how this might be done. Unsolicited articles that cannot be used are not returned.

(11) Contributors will be supplied with a PDF file of their contribution

\section{English Today}

\section{Whose copy are you reading?}

\author{
Have you borrowed a friend's or \\ colleague's copy?
}

Are you reading in a library or are you at
the bottom of a long circulation list?

Why not take out your own subscription?

English Today is published in March, June, September and December

Volume 33, 2017: $£ 186 / \$ 322$;

$£ 27 / \$ 57$ for students and the retired; special rates for members of TESOL, ACTFL, DSNA, AILA \& IATEFL (please enquire). Prices include delivery by air where appropriate. (ISSN 0266-0784) The electronic-only version is available to libraries and institutions at $£ 164 /$ 259 (ISSN 1474-0567)
For further information or to order, contact: Customer Services Department, Cambridge University Press, FREEPOST* ${ }^{*}$, Journals Fulfillment Department, UPH, Shaftesbury Road, Cambridge CB2 8BS, UK,
Tel: +44(0)1223 326070
Fax: +44(0)1223 325150

\section{Email enquiries: journals@cambridge.org}

* No stamp necessary if posted within UK

Enquiries in the USA, Canada and Mexico
should be directed to:
Cambridge University Press,
Journals Fulfillment Department,
1 Liberty Plaza, Floor 20, New York,
NY 10006 , USA
Tel: 8453537500
Fax: 8453534141

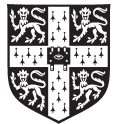

\section{CAMBRIDGE UNIVERSITY PRESS}

This journal issue has been printed on FSC-certified paper and cover board. FSC is an independent, non-governmental, not-for-profit organization established to promote the responsible management of the world's forests.

Please see www.fsc.org for information. 


\section{English Today}

\section{Contents}

\section{Editorial}

Editors' comment

\section{Articles}

Hu, X. and Luo, S. Laoshi, zao shang hao! Good morning, teacher?

Shang, G. and Zhao, S. Bottom-up multilingualism in Singapore: Code choice on shop signs

Ruzaitè, J. Diversity of attitudes to English in non-professional public discourse: A focus on Lithuania

Shao, Q. and Gao, X. 'Noisy guests shall not unseat the host'

Akinlotan, M. and Housen, A. Noun phrase complexity in Nigerian English

Cop, M. and Hatfield, H. An athletes [sic] performance: Can a possessive apostrophe predict success?

$\mathrm{Li}, \mathrm{J}$. Tracing the heritage of Pidgin English in mainland China

Brown, J. Beyond the World Englishes Paradigm: Agency,

Performativity and Malaysian English

\section{Reviews}

Bacchini, S. And then there were many: How no English became one English, and then many

Davydova, J. Teaching Global English

\section{Corrigendum}

Poole, B. ' 'Quality' problems - CORRIGENDUM 